\title{
Knobloch syndrome
}

INSERM

\section{Source}

INSERM. (1999). Orphanet: an online rare disease and orphan drug data base. Knobloch syndrome. ORPHA:1571

Knobloch syndrome (KS) is defined by vitreoretinal and macular degeneration, and occipital encephalocele. 